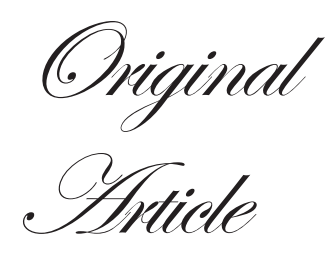

\title{
Ilaprazole: Is this a superior proton pump inhibitor for duodenal ulcer?
}

\author{
NP Bohidar, ${ }^{1}$ K Krishna, ${ }^{2}$ BK Panda ${ }^{3}$ and C Patel ${ }^{4}$
}

\section{ABSTRACT}

Gastroenterology and Hepatology, Rabindranath Tagore International Institute of Cardiac Sciences, Kolkata, West Bengal, ${ }^{1}$ Department of Medicine, Bharati Vidyapeeth Medical College and Hospital, ${ }^{2}$ Department of Clinical Pharmacy (Pharm D programme), Poona College of Pharmacy, Bharati Vidyapeeth Deemed University, ${ }^{3}$ D Pharm, Bharati Vidyapeeth Deemed University, Poona College of Pharmacy, ${ }^{4}$ Pune, Maharashtra, India

Correspondence:

Dr NP Bohidar

Email:nbohidar@hotmail.com
Background: Preclinical studies have found ilaprazole to be significantly effective in preventing the development of reflux oesophagitis and gastric secretion in a dose-dependent manner; the drug also has a broad dose range and safety feature. Till date only one clinical study on patients with gastro-oesophageal reflux disease has shown its potency in suppressing gastric acid secretion.

Objectives: To review the published randomized controlled trials (RCTs) assessing the efficacy of ilaprazole in duodenal ulcer (DU) compared to other available proton pump inhibitors (PPI). Methods: RCTs comparing ilaprazole with other PPIs in DU were searched in the PubMed and Cochrane Library database using the term 'ilaprazole and duodenal ulcer'. All clinical studies showing effectiveness of ilaprazole in patients with DU, either full texts or scientific abstracts and found to be potentially eligible for the systematic review, were included and evaluated. Results: Four RCTs having follow-up data were included. A total of 1077 patients with DU were assessed. All the trials had included omeprazole as a comparator PPI. The majority of patients (80\%) became asymptomatic after treatment in both the groups. None of the trials data predict ilaprazole to be superior to omeprazole in terms of efficacy in patients with DU. Conclusion: The trials conducted were limited in numbers and all the trial data indicated the efficacy of ilaprazole to be similar to that of omeprazole. None of the trials indicated superiority of ilaprazole over the existing PPIs.

KEYWORDS: Ilaprazole, duodenal ulcer, proton pump inhibitor

\section{Introduction}

Proton pump inhibitors (PPIs) are highly effective drugs that are widely used in the treatment of peptic diseases including gastric and duodenal ulcer (DU), reflux oesophagitis and Zollinger-Ellison syndrome. ${ }^{1-3}$ Many new therapeutic drugs with similar structures and better therapeutic outcomes have been developed since omeprazole was first introduced into the market. These new drugs include rabeprazole, pantoprazole, lansoprazole, esomeprazole and the new molecule ilaprazole \{2-[[(4-methoxy-3-methyl)-2-pyridinyl]methylsulfinyl-5-(1H-
pyrrol-1-yl)-1H-benzimidazole, CAS 172152-36-2)\}. It was also called IY81149 (before, MW366.4) which was developed by Il Yang Pharmacy Co. (Seoul, Korea) and was first studied in vivo via experimental animal models of mouse, rats, dogs and pigs. ${ }^{4-6}$ These studies found that ilaprazole significantly prevented the development of reflux oesophagitis and gastric secretion in a dose-dependent manner, ${ }^{4}$ and at the same time had little effect on the animal's cardiovascular system, autonomic nervous system or smooth muscle function from 
0.3 to $1000 \mathrm{mg} / \mathrm{kg}$, indicating that ilaprazole has a broad dose range and safety feature. ${ }^{5,6}$ There was only one clinical study on patients with gastro-oesophageal reflux disease, which showed that administration of 10 and $20 \mathrm{mg}$ ilaprazole produced a statistically significantly greater and prolonged suppression of gastric $\mathrm{pH}$ than $20 \mathrm{mg}$ omeprazole. ${ }^{7}$

The present review aims to critically assess the efficacy of ilaprazole in DU compared to other available PPIs through a systematic search and analysis of various randomized controlled trials (RCTs) published in standard medical databases.

\section{Materials and methods}

Search strategy

Pertinent studies were searched in the PubMed using the term 'ilaprazole and duodenal ulcer' without initiating limits \{(“IY 81149”[Supplementary Concept] OR “IY 81149”[All Fields] OR “ilaprazole”[All Fields]) AND (“duodenal ulcer”[MeSH Terms] OR (“duodenal"[All Fields] AND “ulcer"[All Fields]) OR “duodenal ulcer"[All Fields])\} while advanced search was performed using the term 'ilaprazole' only in Cochrane Library databases (updated till 30 April 2012) by two of the investigators. The search strategy was developed following the Biondi-Zoccai method. The language was restricted to English and the search strategy was set to end on the month of April 2012.

\section{Inclusion criteria}

All clinical studies showing effectiveness of ilaprazole in patients with DU, either full texts or scientific abstracts and found to be potentially eligible for the systematic review, were included and evaluated. Trials were included if safety and efficacy of ilaprazole was assessed in patients with DU. Trials were eligible if ilaprazole was given in comparison with other PPIs such as omeprazole.

\section{Data extraction and analysis}

Two reviewers screened all titles and abstracts independently and irrelevant studies were discarded. The full text of the remaining studies was assessed to determine if the inclusion criteria were met. The same two reviewers assessed the included studies for trial quality, without blinding to author or source. Any issues of discrepancies in quality assessment were discussed and resolved. The quality items assessed were allocation concealment, intention-to-treat analysis, completeness to follow-up, and blinding of outcomes.

\section{Results \\ Literature search}

Four RCTs having follow-up data were included. There was no disagreement between the two reviewers regarding the inclusion of trials. One of the articles was in Chinese language but the English abstract was available. The requested information to allow inclusion of these trials could not be obtained from the authors.

\section{Study characteristics and quality assessments}

The characteristics of the four RCTs are shown in Table 1. A total of 1077 patients with DU were assessed, and all the trials included omeprazole as a comparator PPI. Three trials were multicentric and were comparative RCTs. All the trials were double-blinded but only three trials had adequate allocation concealment (Table 2).

\section{Discussion}

RCTs in endoscopically diagnosed patients with active DU showed a positive healing rate $(>75 \%-93 \%)$ at week 4 in the ilaprazole group. The intervention was compared with

Table 1: Characteristics of studies using ilaprazole in patients with duodenal ulcer (DU)

\begin{tabular}{|c|c|c|c|c|c|c|c|}
\hline $\begin{array}{l}\text { Study } \\
\text { (Reference) }\end{array}$ & Population & $\begin{array}{l}\text { No. of } \\
\text { patients }(n)\end{array}$ & \multicolumn{4}{|c|}{$\begin{array}{l}\text { Drug and doses given to respective groups } \\
\text { (mg/day) }\end{array}$} & Follow-up \\
\hline $\begin{array}{l}\text { Wang et al., } \\
\text { Multicentric study, } 2012\end{array}$ & Patients with DU & 494 & $\begin{array}{l}\text { Ilaprazole } \\
\text { (10) }\end{array}$ & roup & $\begin{array}{l}\text { Omeprazo } \\
(20)\end{array}$ & le group & 4 weeks \\
\hline $\begin{array}{l}\text { Wang et al., } \\
\text { Multicentric study, } 2011\end{array}$ & Patients with DU & 235 & $\begin{array}{l}\text { Ilaprazole } \\
\text { (5) }\end{array}$ & $\begin{array}{l}\text { Ilaprazole } \\
(10)\end{array}$ & $\begin{array}{l}\text { Ilaprazole } \\
(20)\end{array}$ & $\begin{array}{l}\text { Omeprazole } \\
(20)\end{array}$ & 4 weeks \\
\hline $\begin{array}{l}\text { Zhou et al., } \\
\text { Multicentric study, } 2010\end{array}$ & Patients with DU & 42 & $\begin{array}{l}\text { Ilaprazole } \\
\text { (5) }\end{array}$ & $\begin{array}{l}\text { Ilaprazole } \\
(10)\end{array}$ & $\begin{array}{l}\text { Ilaprazole } \\
(20)\end{array}$ & $\begin{array}{l}\text { Omeprazole } \\
(20)\end{array}$ & 5 days \\
\hline $\begin{array}{l}\text { Ho et al, } 11 \\
\text { Singapore, } 2009\end{array}$ & $\begin{array}{l}\text { Gastric and DU } \\
\text { patients }\end{array}$ & $\begin{array}{l}306 \mathrm{DU} \\
\text { patients }\end{array}$ & $\begin{array}{l}\text { Omeprazol } \\
(20)\end{array}$ & $\begin{array}{l}\mathrm{Il} \\
(5\end{array}$ & zole & $\begin{array}{l}\text { Ilaprazole } \\
\text { (10) }\end{array}$ & 4 weeks \\
\hline
\end{tabular}


Table 2: Quality assessment of trials for ilaprazole in patients with duodenal ulcer (DU)

\begin{tabular}{|c|c|c|c|c|c|c|}
\hline $\begin{array}{l}\text { Study } \\
\text { (Reference) }\end{array}$ & $\begin{array}{l}\text { Allocation } \\
\text { concealment } \\
\text { used }\end{array}$ & Blinding & $\begin{array}{l}\text { Intention } \\
\text { to treat }\end{array}$ & $\begin{array}{l}\text { Loss to } \\
\text { follow-up }\end{array}$ & Measurement of outcome & Outcome assessed \\
\hline $\begin{array}{l}\text { Wang et al., }{ }^{8} \mathrm{~A} \\
\text { Multicentric } \\
\text { study, } 2012\end{array}$ & dequate & Double-blind & Not stated & None & $\begin{array}{l}\text { Primary end-point: } \\
\text { Endoscopically diagnosed ulcer } \\
\text { healing rate at week } 4 \text { Secondary } \\
\text { end-point: Symptom relief by } \\
\text { graded scores In addition, } \\
\text { blood samples were collected at } \\
\text { baseline for CYP2C19 genotypes } \\
\text { identification }\end{array}$ & $\begin{array}{l}\text { Ilaprazole ( } 10 \mathrm{mg} / \text { day) is as } \\
\text { effective as omeprazole ( } 20 \\
\mathrm{mg} / \text { day) in the treatment of } \\
\text { DU with similar side-effects. } \\
\text { The efficacy of ilaprazole is } \\
\text { not affected by CYP2C19 } \\
\text { polymorphisms. }\end{array}$ \\
\hline $\begin{array}{l}\text { Wang et al., } \\
\text { Multicentric } \\
\text { study, } 2011\end{array}$ & Adequate & Double-blind & Not stated & None & $\begin{array}{l}\text { Primary end-point: } \\
\text { Endoscopically diagnosed ulcer } \\
\text { healing rate at week } 4\end{array}$ & $\begin{array}{l}\text { Ilaprazole and omeprazole } \\
\text { exhibited similar efficacy and } \\
\text { safety profiles. Gastric acid } \\
\text { suppression increased with } \\
\text { increasing dose of ilaprazole } \\
\text { in the pH study. }\end{array}$ \\
\hline $\begin{array}{l}\text { Zhou et al., }{ }^{10} \\
\text { Multicentric } \\
\text { study, } 2010\end{array}$ & Adequate & Double-blind & Not stated & None & $\begin{array}{l}\text { Fraction time } \mathrm{pH} \text { above } 3 \text {, } \\
4 \text { or } 5 \text {, median values of } 24 \text {-hour } \\
\text { diurnal } \mathrm{pH} \text { and } 12 \text {-hour nocturnal } \\
\mathrm{pH} \text {, the percentage of patients } \\
\text { with total time } \mathrm{pH} \text { above } 3,4 \\
\text { or } 5 \text { at least for } 18 \text { hours were } \\
\text { evaluated }\end{array}$ & $\begin{array}{l}\text { There were no significant } \\
\text { differences observed among } \\
\text { all the groups with different } \\
\text { doses of ilaprazole and } \\
\text { omeprazole. Ilaprazole has a } \\
\text { strong effect on intragastric } \\
\text { acid control with a dose- } \\
\text { dependent trend. }\end{array}$ \\
\hline $\begin{array}{l}\text { Ho et al., }{ }^{11} \\
\text { Singapore, } \\
2009\end{array}$ & Inadequate & Double-blind & Not stated & $\begin{array}{l}29.2 \% \text { of } \\
\text { gastric } \\
\text { ulcer and } \\
15 \% \text { of DU }\end{array}$ & $\begin{array}{l}\text { Primary end-point: } \\
\text { Endoscopically diagnosed ulcer } \\
\text { healing rate at week } 4 \text { Secondary } \\
\text { end-point: Symptom relief by } \\
\text { graded scores safety and } \\
\text { tolerability: clinical assessments }\end{array}$ & $\begin{array}{l}\text { Ilaprazole is as tolerable, safe } \\
\text { and efficacious as } \\
\text { omeprazole in the treatment } \\
\text { of gastroduodenal ulcers, at } \\
\text { a much lower dose ( } 5 \mathrm{vs} \text {. } \\
20 \mathrm{mg} \text { omeprazole). }\end{array}$ \\
\hline
\end{tabular}

omeprazole. The primary end-point for evaluating the efficacy was the healing rate of ulcer at week 4, which was determined through endoscopy. Ilaprazole was administered at various doses of $5 \mathrm{mg}, 10 \mathrm{mg}$ and $20 \mathrm{mg}$ per day. All the trials included omeprazole (20 mg/day) as a comparator drug. The majority of patients $(80 \%)$ became asymptomatic after treatment in both the groups. But none of the trials data predict ilaprazole to be superior to omeprazole in terms of efficacy in patients with DU. Ilaprazole is reported to be as efficacious as omeprazole in healing the ulcer.

A multicentric trial conducted by Wang et al. ${ }^{9}$ in 2011 confirmed ilaprazole as an effective gastric acid suppressor; gastric acid suppression increased with the increasing dose of ilaprazole, viz. $5 \mathrm{mg}, 10 \mathrm{mg}$ and $20 \mathrm{mg}$.

Two registered trials evaluated the efficacy in terms of symptom relief through a graded score technique which served as a secondary end-point. Wang et al. ${ }^{8}$ and Ho et al. ${ }^{11}$ concluded that a majority of patients $(>75 \%)$ became asymptomatic after treatment with ilaprazole, but the comparison with the omeprazole arm did not show any statistically significant difference in symptom relief.

The trial data confirm that ilaprazole is as tolerable and safe as omeprazole. It has side-effects similar to that of omeprazole, such as gastrointestinal (GI) discomfort (e.g. nausea, headache).

\section{Conclusion}

From our overview of RCTs of ilaprazole registered in the medical databases, it can be concluded that the trials conducted so far were limited in numbers and all the trial data indicated the efficacy of ilaprazole similar to that of omeprazole. None of the trials indicated superiority of ilaprazole over the existing PPIs.

\section{References}

1. Welage LS, Berardi RR. Evaluation of omeprazole, lansoprazole, pantoprazole, and rabeprazole in the treatment of acid-related diseases. J Am Pharm Assoc (Wash). 2000;40:52-62 quiz 121-3.

2. Welage LS. Pharmacologic properties of proton pump inhibitors. Pharmacotherapy. 2003;23:74S-80S. 
3. Dekel R, Morse C, Fass R. The role of proton pump inhibitors in gastro-oesophageal reflux disease. Drugs. 2004;64:277-95.

4. Kil BJ, Kim IW, Shin CY, Jeong JH, Jun CH, Lee SM, et al. Comparison of IY81149 with omeprazole in rat reflux oesophagitis. J Auton Pharmacol. 2000;20:291-6.

5. Kwon D, Chae JB, Park CW, Kim YS, Lee SM, Kim EJ, et al. Effects of IY-81149, a newly developed proton pump inhibitor, on gastric acid secretion in vitro and in vivo. Arzneimittelforschung. 2001;51:204-13.

6. Kim EJ, Lee RK, Lee SM, Kim DY. General pharmacology of IY81149, a new proton pump inhibitor. Arzneimittelforschung. 2001;51:51-9.

7. Periclou AP, Goldwater R, Lee SM, Park DW, Kim DY, Cho KD, et al. A comparative pharmacodynamic study of IY-81149 versus omeprazole in patients with gastroesophageal reflux disease. Clin
Pharmacol Ther. 2000;68:304-11.

8. Wang L, Zhou L, Hu H, Lin S, Xia J. Ilaprazole for the treatment of duodenal ulcer: a randomized, double-blind and controlled phase III trial. Curr Med Res Opin. 2012;28:101-9.

9. Wang L, Zhou L, Lin S, Hu H, Xia J. A new PPI, ilaprazole compared with omeprazole in the treatment of duodenal ulcer: a randomized double-blind multicenter trial. J Clin Gastroenterol. 2011;45:322-9.

10. Zhou LY, Lin SR, Yang YS, Zhang ST, Yuan YZ, Shi RH, et al. Evaluation of the effect of ilaprazole on intragastric $\mathrm{pH}$ in patients with duodenal ulcer. Zhonghua Nei Ke Za Zhi. 2010;49:290-2.

11. Ho KY, Kuan A, Zaño F, Goh KL, Mahachai V, Kim DY, et al. Randomized, parallel, double-blind comparison of the ulcerhealing effects of ilaprazole and omeprazole in the treatment of gastric and duodenal ulcers. J Gastroenterol. 2009;44:697-707. 